\title{
Effort to Improve Outcomes Summary Material of Number Through The Problem Based Learning Model
}

\section{Tri Suwarni}

SDN 2 Pagergunung

suwarnitri89@gmail.com

\section{Article History}

ccepted 14/11/2020

approved $21 / 11 / 2020$

published 26/11/2020

\begin{abstract}
The purpose of this study was to improve student learning outcomes in Mathematics in grade III elementary schools with the Problem Based Learning (PBL) learning model. The research conducted was a Classroom Action Research (CAR) in two cycles, with each cycle consisting of two meetings. The stages of each cycle are planning, implementing, observing and reflecting. Each meeting is carried out a pre test and post test to determine the progress of students. In the first cycle the students who completed after carrying out the post test were $59 \%$. In the second cycle students who completed after carrying out the post test were $87 \%$. These results indicate that the Problem Based Learning (PBL) learning model can improve the learning outcomes of students, especially Class III Mathematics at SDN 2 Pagergunung
\end{abstract}

Keywords: Learning outocome,problem based learning,mathematics

\section{Abstrak}

Tujuan dari penelitian ini adalah untuk meningkatkan hasil belajar peserta didik pada mupel Matematika di sekolah dasar kelas III dengan model pembelajaran Problem Based Learning (PBL). Penelitian yang dilakukan adalah Penelitian Tindakan Kelas (PTK) sebanyak dua siklus, dengan setiap siklusnya terdiri dari satu pertemuan. Tahapan setiap siklusnya adalah perencanaan, pelaksanaan, observasi dan refleksi. Setiap pertemuan dilakukan pre test dan post test untuk mengetahui perkembangan peserta didik. Pada siklus I peserta didik yang tuntas setelah melaksanakan post test sebesar 59\%. Pada siklus II peserta didik yang tuntas setelah melaksanakan post test sebesar $87 \%$. Hasil ini menunjukan bahwa model pembelajaran Problem Based Learning (PBL) dapat meningkatkan hasil belajar peserta didik khususnya mupel Matematika Kelas III di SDN 2 Pagergunung.

Kata kunci: Hasil belajar,problem based learning,matematika

Social, Humanities, and Education Studies (SHEs): Conference Series https://jurnal.uns.ac.id/shes

p-ISSN 2620-9284

e-ISSN 2620-9292 


\section{PENDAHULUAN}

Setiap guru pasti mengharapkan pembelajaran yang dilaksanakan berhasil. Sesuai dengan Kurikulum Sekolah Dasar Negeri 2 Pagergunung Pembelajaran disebut berhasil jika hasil belajar melampui batas kriteria ketuntasan minimal (KKM) yang telah ditetapkan. Pada mata pelajaran Matematika operasi hitung bilangan bulat Peserta didik dikatakan berhasil apabila mendapat hasil belajar $>70$. Kenyataan yang terjadi pada Peserta didikkelas III SD Negeri 2 Pagergunung Tahun Pelajaran 2020/2021 menunjukan hanya 4 dari 22 (18\%) Peserta didik yang memperoleh nilai diatas KKM dengan rerata nilai 59 , sehingga pembelajaran dikatakan belum berhasil.

Rendahnya hasil belajar Peserta didik disebabkan oleh beberapa faktor baik dari guru maupun Peserta didik. Pembelajaran yang berpusat pada guru, minimnya penggunaan alat peraga dan penggunaan metode ceramah murni merupakan faktor dari guru. Selain hal tersebut meskipun sudah kelas III sebagian besar Peserta didik di SD Negeri 2 Pagergunung belum mnguasai konsep operasi hitung bilanggan cacah, sehingga hasil belajarnya rendah.

Menurut Bunyamin S. Bloom, dkk (1956) hasil belajar dapat dikelompokkan kedalam tiga domain yaitu kognitif, afektif dan psikomotor. (Zaenal Arifin, 2009: 39)

Domain kognitif (cognitive domain), yaitu kemampuan dalam memahami pengetahuan.

Domain afektif (affective domain), yaitu internalisasi sikap yang menunjuk kearah pertumbuhan batiniah dan terjadi bila peserta didik menjadi sadar tentang nilai yang diterima, kemudian mengambil sikap sehingga menjadi bagian dari dirinya dalam membentuk nilai dan menentukan tingkahlaku.

Domain psikomotor, yaitu kemampuan peserta didik yang berkaitan dengan gerakan tubuh atau bagian-bagiannya, mulai dari gerakan yang sederhana sampai dengan gerakan yangkompleks.

Penggunaan model pembelajaran yang tepat sangat berperan dalam menanamkan konsep. Jika konsep telah matang maka kemungkinan hasil belajar akan baik. Hal ini mendorong guru untuk berinovasi dalam pembelajaran dengan menerapkan model problem based learning sehingga pembelajran tidak lagi berpusat pada guru dan keaktifan Peserta didik meningkat. Problem-Based Learning (PBL) atau Pembelajaran Berbasis Masalah (PBM) adalah metode pengajaran yang bercirikan adanya permasalahan nyata sebagai konteks untuk para Peserta didikbelajar berfikir kritis dan keterampilan memecahkan masalah, dan memperoleh pengetahuan (Duch, 1995). Finkle dan Torp (1995) menyatakan bahwa PBM merupakan pengembangan kurikulum dan sistem pengajaran yang mengembangkan secara simultan strategi pemecahan masalah dan dasar-dasar pengetahuan dan keterampilan dengan menempatkan para Peserta didikdalam peran aktif sebagai pemecah permasalahan sehari-hari yang tidak terstruktur dengan baik. Dua definisi di atas mengandung arti bahwa PBL atau PBM merupakan setiap suasana pembelajaran yang diarahkan oleh suatu permasalahan sehari-hari.

Menurut Boud dan Felleti (1991, dalam Saptono, 2003) menyatakan bahwa "Problem Based Learning is a way of constructing and teaching course using problem as a stimulus and focus on student activity". H.S. Barrows (1982), sebagai pakar PBL menyatakan bahwa definisi PBL adalah sebuah metode pembelajaran yang didasarkan pada prinsip bahwa masalah (problem) dapat digunakan sebagai titik awal untuk mendapatkan atau mengintegrasikan ilmu (knowledge) baru.. PBL adalah metode belajar yang menggunakan masalah sebagai langkah awal dalam mengumpulkan dan mengintegrasikan pengetahuan baru (Suradijono, 2004)

Berdasarkan identifikasi masalah dan analisis masalah serta uraian tersebut di atas yang menjadi fokus rumusan masalahnya adalah: "Bagaimanakah meningkatkan hasil belajar materi penjumlahan bilangan cacah dengan model Problem Based 
Learning di kelas III SD Negeri 2 Pagergunung?. Oleh karena hal tersebut diatas peneliti berusaha mencari solusi pemecahan masalah rendahnyya hasil belajar Peserta didik dengan melakukan penelitian tindakan tindakan kelas dengan judul "UPAYA PENINGKATAN HASIL BELAJAR MATERI PENJUMLAHAN BILANGAN CACAH MELALUI MODEL PROBLEM BASED LEARNING KELAS III SDN 2 PAGERGUNUNG TAHUN PELAJARAN 2020/2021"

Dengan mendasarkan permasalahan yang ada, maka tujuan penelitian tindakan kelas ini adalah:

Untuk mengetahui apakah model Problem based Learning dapat meningkatkan hasil belajar operasi hitung bilangan cacah pada Peserta didik kelas III SDN 2 Pagergunung Semester I Tahun Pelajaran 2020/2021?

Untuk mengetahui berapa besar peningkatan hasil belajar operasi hitung bilangan cacah pada Peserta didik kelas III SDN 2 Pagergunung Semester I Tahun Pelajaran 2020/2021 menggunakan model Problem based Learning?

\section{METODE}

Penelitian ini adalah penelitian tindakan kelas (Classroom Action Research) dengan menerapkan model pembelajaran Problem Based Learning (PBL). Dalam penelitian tindakan model Kemmis \& McTaggart terdiri dari empat komponen, yaitu (1) perencanaan (planning), (2) tindakan (acting), (3) pengamatan (observing), dan (4) refleksi (reflecting).Analisis penelitian ini adalah analisis deskriptif kuantitafif kualitatif dimana dalam penelitian ini selain penyajian hasil berupa data maupun angka peneliti juga menentukan bagaimana cara pengolahan hasil penelitian yakni dengan membuat analisisnya dengan menerapkan model penelitian Problem Based Learning (PBL). Penelitian ini dilaksanakan pada peserta didik kelas III SD Negeri 2 Pagergunung Tahun Pelajaran 2020/2021 selama dua siklus secara luring dengan satu pertemuan disetiap siklusnya. Siklus I dilaksanakan pada tanggal 16 dan November 2020. Siklus II dilaksanakan pada tanggal 23 November 2020.Teknik pengumpulan data yang dilakukan dengan observasi dan tes, baik pre test maupun post test. Observasi meliputi observasi keterlaksanaan model pembelajaran Problem Based Learning, sikap peserta didik dan keterampilan. Untuk hasil belajar menggunakan tes.

\section{HASIL DAN PEMBAHASAN}

Pada siklus I model pembelajaran dengan menggunakan Problem Based Learning belum dilaksanakan secara optimal oleh guru. Pada akhir pembelajaran, setelah guru mengadakan evaluaai ternyata nilai yang diperoleh peserta didik belum sesuai dari yang diharapkan. Peneliti bersama teman sejawat mencari permasalahan tersebut.

Tabel 1. Hasil Evaluasi Belajar Siklus I

Mata Pelajaran Matematika Materi penjumlahan Bilangan Cacah

\begin{tabular}{cccccc}
\hline No & $\begin{array}{c}\text { Skor } \\
(\mathrm{S})\end{array}$ & $\begin{array}{c}\text { Frekuensi } \\
(\mathrm{F})\end{array}$ & $\begin{array}{c}\text { Prosentase } \\
(\%)\end{array}$ & S X F & Keterangan \\
\hline 1 & 50 & 0 & $0 \%$ & 0 & Belum Tuntas \\
2 & 60 & 9 & $41 \%$ & 540 & Belum Tuntas \\
3 & 70 & 8 & $36 \%$ & 560 & Tuntas \\
4 & 80 & 5 & $23 \%$ & 400 & Tuntas \\
5 & 90 & 0 & $0 \%$ & 0 & Tuntas \\
6 & 100 & 0 & $0 \%$ & 0 & Tuntas
\end{tabular}




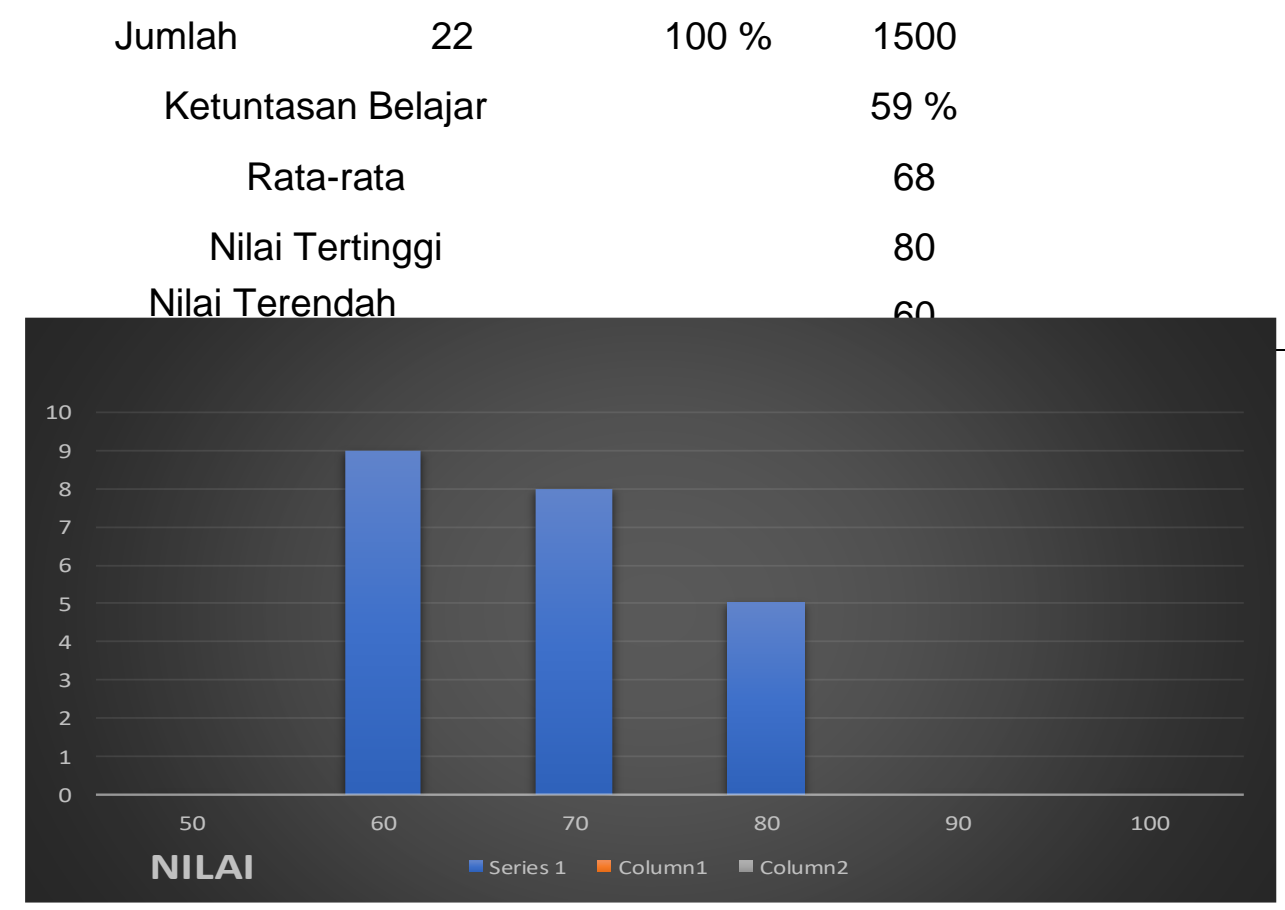

Gambar 1. Grafik Hasil Analisis Evaluasi Belajar Siklus I Mata Pelajaran Matematika Materi Penjumlahan Bilangan Cacah

Kesimpulannya peserta didik belum dapat memahami serta menguasai materi penjumlahan bilangan cacah dengan tepat. Untuk memperbaiki dan meningkatkan prestasi belajar peserta didik, maka pada siklus I guru berupaya meningkatkan prestasi belajar peserta didik materi penjumlahan bilangan cacah melalui melalui problem based learning. Selain itu guru berupaya semaksimal mungkin untuk menciptakan suasana belajar yang lebih aktif, kreatif, dan menyenangkan.

Dari hasil pengamatn pada perbaikan siklus I dari 22 peserta didik terdapat 13 peserta didik yang mendapatkan niali di bawah KKM. Setelah direnungkan dalam tahap refleksi ternyata terdapat factor-faktor yang mempengaruhi kekurang keberhasilan peserta didik antara lain :

a. Penerapan model problem based learning kurang optimal, sehingga perhatian peserta didik masih kurang pada waktu guru memberikan penjelasan materi

b. Peserta didik masih kurang berani bertanya kepada guru apabila menemukan kesulitan dalam memahami materi penjumlahan bilangan cacah.

Kegiatan tersebut pada siklus I sudah berhasil meningkatkan hasil belajar namun belum sepenuhnya tercapai ketuntasan belajar.

Hasil evaluasi pada akhir siklus I, rata-rata 68 sudah meningkat dari rata- rata sebelum perbaikan pembelajaran yaitu 59. Demikian pula prosentase ketuntasan belajar meningkat dari jumlah peserta didik yang tuntas $18 \%$ menjadi $59 \%$

Menindaklanjuti dari hal tersebut maka peneliti perlu mengadakan perbaikan pembelajaran siklus II untuk meningkatkan hasil pembelajaran yang hendak dicapai. Pada siklus ke II guru tetap menggunakan model problem based learning dalam meningkatkan hasil belajar dan pemahaman peserta didik tentang materi penjumlahan bilangan cacah. 
Tabel 2. Hasil Evaluasi Belajar Siklus II Mata Pelajaran Matematika Materi penjumlahan Bilangan Cacah

\begin{tabular}{|c|c|c|c|c|c|}
\hline No & $\begin{array}{l}\text { Skor } \\
\text { (S) }\end{array}$ & $\begin{array}{l}\text { Frekuensi } \\
\text { (F) }\end{array}$ & $\begin{array}{c}\text { Prosentase } \\
(\%)\end{array}$ & $S \times F$ & Keterangan \\
\hline 1 & 50 & 0 & $0 \%$ & 0 & Belum Tuntas \\
\hline 2 & 60 & 2 & $9 \%$ & 120 & Belum Tuntas \\
\hline 3 & 70 & 0 & $0 \%$ & 0 & Tuntas \\
\hline 4 & 80 & 11 & $50 \%$ & 880 & Tuntas \\
\hline 5 & 90 & 0 & $0 \%$ & 0 & Tuntas \\
\hline 6 & 100 & 9 & $41 \%$ & 900 & Tuntas \\
\hline & nlah & 22 & $100 \%$ & 1900 & \\
\hline \multicolumn{3}{|c|}{ Ketuntasan Belajar } & \multicolumn{3}{|c|}{$91 \%$} \\
\hline \multicolumn{3}{|c|}{ Rata-rata } & \multicolumn{3}{|c|}{86} \\
\hline \multicolumn{3}{|c|}{ Nilai Tertinggi } & \multicolumn{3}{|c|}{100} \\
\hline \multicolumn{3}{|c|}{ Nilai Terendah } & \multicolumn{3}{|c|}{60} \\
\hline
\end{tabular}

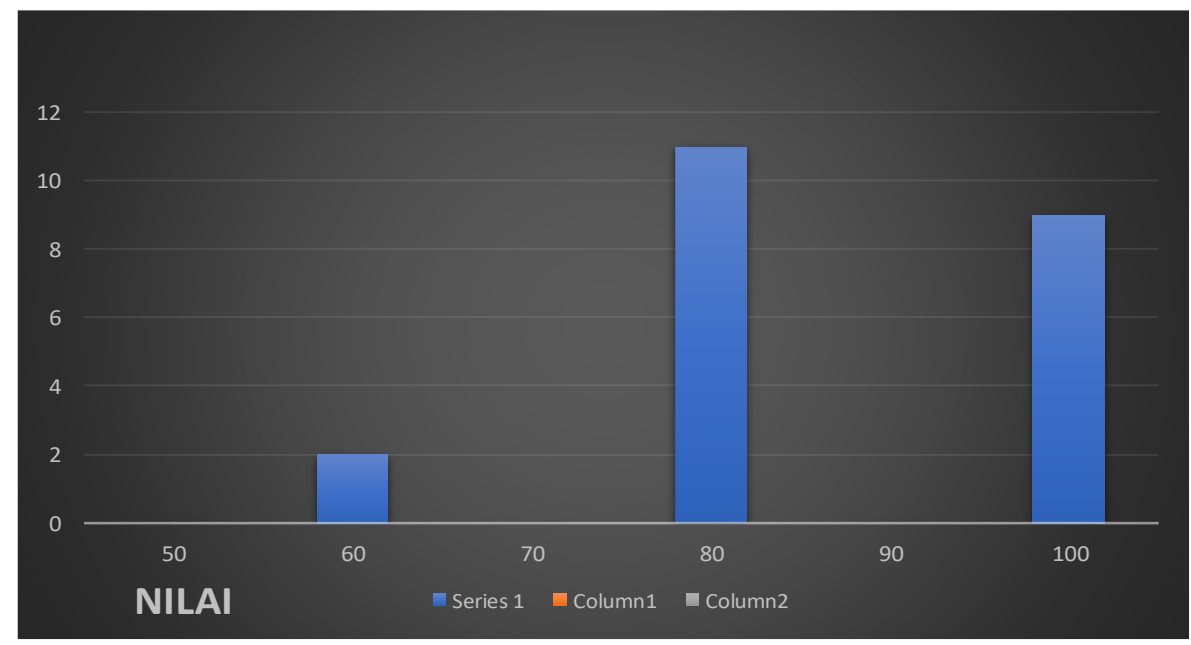

Gambar 3. Grafik Hasil Analisis Evaluasi Belajar Siklus I I Mata Pelajaran Matematika Materi Penjumlahan Bilangan Cacah

Proses pembelajaran siklus II sudah menunjukkan adanya peningkatan. Hal ini dapat dilihat dari meningkatnya nilai rata-rata evaluasi dari siklus I yaitu 68 menjadi 86. Peningkatan hasil rata-rat ini dikarenakan guru dalam proses pembelajaran menggunakan model problem based learning dalam materi penjumlahan bilangan cacah.

PROBLEM BASED LEARNING (PBL) merupakan metode pembelajaran yang mendorong Peserta didik untuk mengenal cara belajar dan bekerjasama dalam kelompok untuk mencari penyelesaian masalah-masalah di dunia nyata. Simulasi masalah digunakan untuk mengaktifkan keingintahuan Peserta didik sebelum mulai mempelajari suatu subyek. PBL menyiapkan Peserta didik untuk berpikir secara kritis 
dan analitis, serta mampu untuk mendapatkan dan menggunakan secara tepat sumber-sumber pembelajaran.

Pada perbaikan proses pembelajaran siklus II ini penggunaan model problem based learning dalam menanamkan materi penjumlahan bilangan cacah lebih dioptimalkan agar peserta didik terlibat secara aktif. Setelah dipraktikkan dalam proses pembelajaran kemudian dilaksanakan evaluasi ternyata membuahkan hasil yang cukup memuaskan.

Hal ini membuktikan bahwa pelaksanaan pembelajaran siklus II menumbuhkan minat peserta didik untuk mengikuti pelajaran sangat tinggi. Hal tersebut karena dari awal dan selama pembelajaran peserta didik sudah tertarik dan tertantang untuk menyelesaikan rangkaian pembelajaran karena guru memvariasi pembelajaran dengan menggunakan video dan kartu bilangan, dalam kondisi belajar yang menyenangkan,

Berdasarkan dari data di atas maka peneliti tidak melanjutkan perbaikan, karena hasil yang dicapai pada siklus II telah mengalami peningkatan yang signifikan. Peserta didik yang telah mencapai ketuntasan belajar pada siklus II berjumlah 20 peserta didik atau $91 \%$ dengan rata-rata 86 . Adapun 2 orang peserta didik yang belum berhasil mencapai ketuntasan belajar pada siklus II akan dilakukan bimbingan khusus melalui program perbaikan.

Secara keseluruhan peningkatan nilai rata-rat dan ketuntasan belajar hasil evaluasi siklus I dan siklus II melalui model problem based learning meningkatkan hasil belajar peserta didik dalam memahami materi penjumlahan bilangan cacah di kelas III semester I tahun Pelajaran 2020/2021 SDN 2 Pagergunung kecamatan Bulu kabupaten Temanggung, disajikan pada tabel dan grafik di bawah ini

Tabel 3. Hasil Evaluasi Belajar Siklus I dan Siklus II Materi Penjumlahan Bilangan Cacah

\begin{tabular}{ccc}
\hline & Siklus I & Siklus II \\
\hline Nilai terendah & 60 & 60 \\
Nilai tertinggi & 80 & 100 \\
Rata - rata & 68 & 86 \\
Ketuntasan & $59 \%$ & $91 \%$ \\
\hline
\end{tabular}

Hasil yang positif telah dicapai selama perbaikan pembelajaran untuk meningkatkan prestasi belajar peserta didik materi penjumlahan bilangan cacah kelas III semester I tahun 2020/2021 SDN 2 pagergunung, Kecamatan Bulu , Kabupaten Temanggung. Dapat dilihat dari hasil evaluasi setiap siklus. Pada siklus I nilai rata-rata peserta didik mengalami peningkatan menjadi 71 dengan prosentase ketuntasan $59 \%$ dan pada siklus II nilai rata-rata peserta didik mengalami peningkatan lebih baik menjadi 87 dengan prosentase ketuntasan $91 \%$.

\section{SIMPULAN}

Berdasarkan hasil penelitian dan pembahasan, maka dapat disimpulkam bahwa melalui penerapan Problem Based Learning dapat meningkatkan hasil belajar materi penjumlahan bilangan cacah pada peserta didik kelas III SDN 2 Pagergunung Kecamatan Bulu Kabupaten Temanggung. Kemampuan menyelesaikan penjumlahan bilangan cacah dengan penerapan model Problem Based Learning mengalami peningkatan dari siklus 1 sampai siklus 2, pada siklus 1 peserta didik yang tuntas KKM 
sebanyak 13 peserta didik dengan presentase $59 \%$ dari 22 peserta didik, dan pada siklus ke 2 terjadi peningkatan sebanyak 20 peserta didik dengan presentase $91 \%$ dari 22 peserta didik dengan $\mathrm{KKM} \geq 70$

\section{DAFTAR PUSTAKA}

Bloom, Benjamin S., etc. 1956. Taxonomy of Educational Objectives : The Classification of Educational Goals, Handbook I Cognitive Domain. New York : Longmans, Green and Co.

Duch. (1995). Pembelajaran Berbasis Masalah. Jakarta: Sejarah Indonesia. Finkle dan Torp. (1995). Pembelajaran Berbasis Masalah Merupakan Pengembangan

Saptono, R (2003) Is problem based learning (PBL) a better approach for engineering education? CAFEO-21 (21st Conference of the Asian Federation of Engineering Organization), 22-23 October 2003, Yogyakarta

(Suradijono, 2004)Problem Based Learning: Makalah Seminar Penumbuhan Inovasi Sisitem pembelajaran:Pendekatan Problem Based

(Zaenal Arifin, 2009: 39).Evaluasi Pembelajaran Bandung.:PT. Remaja Rosdakarya 